\title{
Author Correction: Three-phase electric power driven electroluminescent devices
}

\author{
Junpeng Ji, Igor F. Perepichka (1D, Junwu Bai, Dan Hu, Xiuru Xu, Ming Liu, Tao Wang, Changbin Zhao, \\ Hong Meng (1) \& Wei Huang (1)
}

Correction to: Nature Communications https://doi.org/10.1038/s41467-020-20265-2, published online 4 January 2021.

The original version of this Article contained an error in the title, which was previously incorrectly given as 'Three-phase electric power driven electoluminescent devices'. The correct version states 'electroluminescent' in place of 'electoluminescent'.

This has been corrected in both the PDF and HTML versions of the Article.

Published online: 18 January 2021

\begin{abstract}
(c) (i)
Open Access This article is licensed under a Creative Commons Attribution 4.0 International License, which permits use, sharing, adaptation, distribution and reproduction in any medium or format, as long as you give appropriate credit to the original author(s) and the source, provide a link to the Creative Commons license, and indicate if changes were made. The images or other third party material in this article are included in the article's Creative Commons license, unless indicated otherwise in a credit line to the material. If material is not included in the article's Creative Commons license and your intended use is not permitted by statutory regulation or exceeds the permitted use, you will need to obtain permission directly from the copyright holder. To view a copy of this license, visit http://creativecommons.org/licenses/by/4.0/.
\end{abstract}

(C) The Author(s) 2021 